\title{
RESISTING CLOSURE: THE REPRESENTATION OF OPHELIA ON PAINTING AND SCREEN
}

Érika Viviane Costa Vieira*

\begin{abstract}
:
\end{abstract}
Based on representations of the character of Ophelia in visual arts and in the readings of traditional literary criticism of Shakespeare, this paper seeks to question a perverse aesthetics that conjoins women and death.

KEY WORDS: Ophelia, Shakespeare, Hamlet, feminist criticism, visual arts.

Considering the fact that the traditional criticism of Shakespeare had neglected an investigative and serious critical analysis of the famale characters for at least three hundred years (Guedes, 2002), the present work intends to discuss the compensatory process by which the character of Ophelia from the well known play Hamlet has undergone. Ignored and misread by traditional literary criticism that assumed that female characters "occupied a subordinate place in Shakespeare's plays" (Guedes, 2002: 01), Ophelia has found its place in the realm of the visual arts. If Hamlet is whom manipulates the attention of literary criticism with its intriguing existential problems, Ophelia is a protagonist of the visual arts. By recovering the most significative works of its iconography, which starts in the middle of eighteenth century and goes till nowadays, we are able to uncover some of the deadlocks concerning the representation of femininity.

In fact, the interrelation of the arts with Ophelia as subject offers us a new focus for gender studies from a comparative perspective. Shakespeare provided us with one of the most touching descriptions of a woman's death ever produced.

|* Mestre em Letras: Literatura e outros Sistemas Semióticos (Ārea de concentração: Literaturas de Expressão Inglesa), 2004 


\section{EMTESE}

Belo Horizonte, v. 9, p. I-28I, dez. 2005

Motivated by Edgar Allan Poe's famous statement in the nineteenth century that defines the ideal poetic topic as that of a beautiful dead woman, Ophelia has become a recurrent theme since then. Almost an obsession to painters and poets of Poe's era, her figure reveals the perversity behind the gaze that transformed the ideal of femininity into a morbid image: Ophelia's drowning does not encompass a sense of suffering. Instead, the moment of her death is usually reproduced as aesthetically pleasing.

Given Poe's aesthetic and the constant reproducibility throughout the years, pictures based upon the character of Ophelia have made of her character a myth of eternal beauty and a symbol of female perfection. It is unquestionable that, by dying prematurely and peacefully in nature's arms, Ophelia has become an icon of death, which has been translated into a moment of feminine aesthetic beauty immortalized in works of art. Looking for ways to explore the dramatic effect of this single moment, pictures and films have contributed to form and construct Ophelia, by expanding the possibilities of her myth in a myriad of ways. Pictures have consecrated her as the beautiful woman who dies tragically or a typical case of female lunacy. Films have tended to privilege her performances as an icon of female insanity, but an emphasis is added on her character as a player of subversion and resistance, whose death is a matter of controversy to filmmakers who interpret it as either accident or suicide.

The earliest visual representations of Ophelia appeared in illustrated editions of Hamlet in the 1740s. Since then, paintings based on this Shakespearean character have never ceased appearing. Artists and film directors fixed/defined the image and identity of women through the character of Ophelia due to the fact that we are dealing with the representation of women through her character. Hence, it is inevitable not to mention the specificities related to gender which the representations have undergone throughout time. In this sense, it was necessary to take into consideration the conditions gender politics in general was subjected to in each era, on stage, on canvas, or on screen.

Using the concepts of representation (Mitche11, 1995; Brooker, 1999; Hal1, 1997), and of translation (Diniz, 1999), we analyzed the inter-art relationship that has undergone in the case of Ophelia's character as it appears in paintings and 
in film. To Mitchell and Brooker the concept of representation is the traditional standard notion that we substitute something or someone for a sign for someone (Mitche11, 1995: 12-14; Brooker, 1999: 192-93). However, what is of interest here is the representation of Ophelia in its combination of three aspects: femininity, madness, and death, which have always delighted artists. Mitchell and Brooker's definitions, though elucidating, cannot cope with the specificities of the issue we are dealing with because the set of paintings and films analyzes Ophelia as representation/translation of woman.

Therefore, as we recognize femininity as a cultural construct, a form of representation; madness as a deviant, subversive discourse, and death in the site of "the other," the notion of representation proposed by Stuart Hall (1997) seems to be the most appropriate in the case. For him, the representation of "the 0ther" is a representation of "difference," which happens by the use of stereotypes (Hall, 1997: 8). According to this perspective, the representational practice is possible because it is firmly grounded on culture, which depends primarily on the production and exchange of meaning $(1997: 2)$. The specific place where this signifying production happens has a crucial position in Hall's perspective due to the fact that meaning is linked to identity: "[m] eaning is what gives us a sense of our own identity, of who we are and with whom we 'belong' " (Hall, 1997: 3).

Hall's notion of representation is a critique of the idea of gender politics organized according to the binary male/female which makes meaning ambivalent and the question of representation of the female character more complex (cf. Hall, 1997: 8). Most of the symbolic value that circulates in the Opheliana deserves a proper analysis for representing a cultural practice. Furthermore, because those images are focused on madness and death, and approached by sane (not mad) and living (not dead) people, they present some dilemmas for the realm of representation. That is, depictions of Ophelia do not convey a personal experience, but stand for a convention that has consecrated them as "beautiful," even with such morbid subjects as madness and death.

This aesthetics that perversely conjoins "woman", "madness" and "death" and permeates the Opheliana signals to an attempt at the elimination of aspects that are linked to absence, chaos, fragmentation, and mortality allegorically embodied 


\section{EMTESE}

Belo Horizonte, v. 9, p. I-28I, dez. 2005

through her figure. According to the studies by Elizabeth Bronfen on Lacan, "woman" is seen as a symptom of absence that our culture represses continually (1992: 207). It happens because "the fear of death translates into a fear of woman, who, for man, is death" (205). In this way, woman stands for death, elimination, castration, disrupting man's sense of integrity and stability. We must bear in mind that woman stands for death in a multitude of ways in Western culture: she is a mystery, Freud's "dark continent", a figure of silence, erasure; "supplement" to man, fluid, undifferentiated, "whose function is to define man" (209). Hence, the representations of dead women, linking death to a plethora of myths of femininity, serve to bring back to man a sense of integration and cohesion, by eliminating the figure of woman, by representing her dead.

The notions of "masculinity" and "femininity" are key terms defined according to Lacan psychoanalysis. For Bronfen, woman functions as a sign of the essence of femininity (1992: 209), but it is considered to be "unrepresentable" (205), for its meaning "is bound to common usage of language" that defines "man" and "woman" according to their anatomic design; femininity, on the other hand, is taken as a broader notion that considers the positions from which each "gender emerges, as well as what signifieds they serve to articulate" (210). So, Bronfen understands femininity from Lacan's insistence on its structural construction, as a signifier (210), responsible for the meanings that come up in the semantic encodings. Bronfen's presentation of Lacanian positions for masculinity and femininity in relation to cultural laws, to the unconscious, to imaginary objects of desire and to the nonsemiotic real only reinforces that the terms are engaged into a structural process that allows its deconstruction and, therefore, avoids essentialism and mystification. Therefore, femininity must be taken as signifier, as a cultural construct, where the relationship of the woman figure and her traits to death and absence genders death and tells "the story of male desire by performing the absence of woman and by producing woman as text, as pure representation" (Teresa de Lauretis qtd in Bronfen, 1992: 208). In this way, our culture uses the figure of women as "a symptom for man's yearning for full identity, ego coherence, and for narcissistic pleasure", as a means to project his lack on her (212).

As humanity cannot grasp the idea of death (because we are not dead) it only reaches us through the sense of loss and helplessness left by someone else's 
departure. As a result, both the female body and human death can be represented on a tropological basis. Representing death and femininity is to stage absence as a form of re-presentation, as a paradoxical possibility of constant return to life itself, as a reminder of our fear of nothing, despair, and absence.

In order to represent death as a manifestation of male power, the female figure serves as mediator: "[t]he dying woman functions as mediatrix between painter and the absolute" (Bronfen, 49), between the signifiers (pictures) and signifieds (death). In this sense, the representation of dead women comes to reassure the sense of absence and negativity which has been linked to women for centuries. By contrasting the characters of Hamlet and Ophelia, the play casts the hero on the side of culture, and logic, while the heroine is placed on the side of nature, negativity, insufficiency, and lack. Her premature death, thus, becomes an overstatement, for the conjunction of woman and death are reminders of absence, evoking the same signifieds.

By tracing the evolution of Ophelia as the archetype of madwoman, fragility, victim, and suicidal maiden in at least four realms: the literary, the mythic, the pictorial, and the filmic we found out that this character has resisted the constraints of traditional literary criticism of Hamlet and, with the contribution of feminist criticism (Showalter, 1993, 1987; Dane, 1998; Guedes, 2002; Neely, 1987; Santos, 1992; Ronk, 1994; Rose, 1985; Thompson, 1988), it has been resexualized and re-dimensioned by being included not only in the literary realm, but also in the pictorial. The pictorial tradition reveals that Ophelia has been more than an obsessive theme to artists throughout various times. From the sample paintings analyzed, Ophelia's body is gradually dissolved from realistic portraits to impressionistic or symbolic abstractions, where her character represents a blank canvas on which artists could inscribe the ideal of femininity that best suits their purposes.

Ophelia is assuredly not the center of the play, nor is her story its nucleus. Often associated with whiteness, silence, and flower buds, her figure stands for an unfulfilled expectation, a promise, a life-to-be, and therefore a blank page, a white canvas, or a blank screen on which writers, literary critics, painters, and filmmakers can create characters that most suit their purposes. 


\section{EMTESE}

Belo Horizonte, v. 9, p. I-28I, dez. 2005

Paradoxically, it is exactly its elusiveness in the text that explains the innumerable possibilities for the reproductions based upon this character. This level of reproducibility achieved by this figure even in our contemporary time has made of Ophelia's character an archetype of pathos in literature and a muse for painters. Thus, (re-) presentations of Gertrude's poetic construction of Ophelia, according to this perspective, are in consonance with the postmodern culture that enters into a dialogue with the pictorial tradition through parodies, privileges the representation as signifier, and treats even reality itself as simulacra (cf. Hutcheon, 1985).

Besides providing a site for reproducibility, Ophelia's elusiveness in the text has contributed to form an aesthetics symbolized by the union of three icons - woman, water, and death - in a recipe dictated by Edgar Allan Poe as the ideal items of a good poem. This ideal aesthetics would control tastes during the nineteenth century and continues to be pervasive nowadays. The popularization of the vulnerable side of this character during the nineteenth century has contributed to assert and assure a reading of Hamlet that does not favour women and certainly was not Shakespeare's. Ophelia, among other female characters, became a popular subject, aiming at convincing women of their place in the Victorian society (cf. Gilbert \& Gubar, 1985). Be it dispersed in literary criticism or in the media in general, the image of the beautiful drowning woman has gained different contours, but has never abandoned the stereotype as victim and vulnerable character. This myth of Ophelia as pathos has somewhat guided the taste and the imagination of artists in relation to women for many centuries.

On the other hand, we must recognize that the advent of gender studies has contributed to dismantle the influence that those images exerted on our preconceptions regarding the nature of women. It was, undoubtedly, the feminist readings of Hamlet that proposed a breakthrough to tell the "history" of Ophelia as her "history" being that of the visual arts (Showalter, 1987). Unfortunately or not, Ophelia's characterization seems to be re-told through the decodification of other signs apart from the verbal ones, such as the pictorial and the cinematic.

The ideas developed throughout have demonstrated that the articulation among the arts is a process of constant production of meaning which overcomes conceptual boundaries and classification. We came to the conclusion that Ophelia's 
death occurs on visual terms, whereas this issue remains as a figure of speech in the text. It means that the dead Ophelia we have come to know in the water is a product of a painter's imagination. In this way, literature and visual arts act infinitely complementing one another, allowing verbal language to superimpose on imagery as a process similar to art criticism, which determines what is and what is not, in an endless mirroring game. What we have in our society is an infinite net of circling ideas; constantly open, in a huge interweaving of texts.

The fact is that the image of the beautiful drowning woman is pervasive and it has survived different artistic experimentations and has gained different contours, resisting the constraints of definite sign systems. As a result, it has impregnated the critical literary tradition with touches of both sentimental victimization and vulnerability, or wildness and indecency, as an influence of the artistic tendencies. Hence, have woman, water, and death been united forever reproducing the stereotype, to be the most touching poetic image, as Edgar Allan Poe suggested?

RESUMO :

Baseado nas representações da personagem Ofélia nas artes visuais e nas leituras da crítica literária tradicional de Shakespeare, este ensaio questiona a estética perversa que une mulher e morte.

PALAVRAS-CHAVE: Ofélia, Shakespeare, Hamlet, crítica feminista, artes visuais.

WORKS CITED

Bronfen, Elizabeth. Over Her Dead Body: Death, Femininity and the Aesthetic. New York: Routledge, 1992.

Brooker, Peter. Representation. In: A Concise Glossary of Cultural Theory. London, Sydney, Auckland: Oxford University Press, p. 192-93, 1999.

Dane, Gabriele. "Reading Ophelia's Madness." Exemplaria. v. 10.2, 1998, <http://www.english.ufl.edu/exemplaria/ danefram.htm>. 28 August 2002.

Diniz, Thaïs F. N. Literatura e cinema: da semiótica à tradução cultural. Ouro Preto: Editora UFOP, 1999. 
Gilbert, S.; Susan Gubar. The Madwoman in the Attic: The Woman Writer and the Nineteenth Century Literary Imagination. Yale UP, 1985.

Guedes, Peonia Viana. Dialogando com Shakespeare: Uma Versão Feminista Contemporânea de King Lear em $A$ Thousand Acres, de Jane Smiley. GT A Mulher na Literatura/XVII Encontro da ANPOLL (2002): 9 pages. 26-28 Jun. 2002. 2 Nov. 2004. <http://www.amulhernaliteratura.ufsc.br/ artigo_peonia2.htm>.

Hal1, Stuart. Introduction. Representations: Cultural Representations and Signifying Practices. Ed. Stuart Hal1. London, etc.: SAGE Publications, in association with The Open University, p. 1-11, 1997.

Humm, Maggie. The Dictionary of Feminist Theory. Columbus: Ohio State UP, 1995.

Hutcheon, Linda. A Theory of Parody: The Teachings of Twentieth-Century Art Forms. London and New York: Methuen \& Co., 1985.

Lacan, Jacques. Hamlet, por Lacan. In.: Shakespeare, Duras, Wedekind, Joyce. Trad. Eunice Marinho. Lisboa: Assírio \& Alvim, 1989.

Mitchel1, W.J.T. Representation. Critical Terms for Literary Study, ed. Frank Lentricchia and Thomas McLaughlin. Chicago: University of Chicago Press, p. 11-22, 1995.

Neely, Carol Thomas. Feminist Criticism and Teaching Shakespeare. ADE Bulletin, v. 87, p. 15-18, Fall 1987. <http://www.mla.org/ade/bulletin/n087/087015.htm> 25 August 2003.

Poe, Edgar Allan. The Poetic Principle. The Poems and Three Essays on Poetry. R. Brimley Johnson (Ed.). London and New York: 0xford UP, p. 165-187, 1927.

. The Philosophy of Composition. The Poems and Three Essays on Poetry. R. Brimley Johnson (Ed.). London and New York: Oxford UP, p. 189-202, 1927.

Ronk, Martha C. "Representations of Ophelia." Criticism, v. 36, p. 21-43, 1994.

Rose, Jacqueline. "Sexuality in the Reading of Shakespeare: Hamlet and Measure for Measure." Alternative Shakespeares. Ed. John Drakakis. London and New York: Methuen, p. 95-118, 1985.

Santos, Marlene Soares dos. Shakespeare e a crítica feminista. Caderno de Letras da UFRJ, Rio de Janeiro, v. 8, p. 119-26, 1992.

Shakespeare, William. Hamlet. New York: Dover Thrift Editions, 1992.

Showalter, Elaine. Female Malady: Women, Madness and the English Culture 1830-1980. New York: Penguin Books, 1987 .

- Representing Ophelia: Women, Madness, and the Responsibilities of Feminist Criticism. Shakespeare and the Question of Theory. Ed. Patricia Parker and Geoffrey Hartman. New York: Routledge, p. 77-94, 1993.

Thompson, Ann "The Warrant of Womanhood: Shakespeare and Feminist Criticism. The Shakespeare Myth. Ed. Graham Holderness. New York: Manchester University Press, p.7488, 1988. 